\title{
An Evaluation Index for the Wound, Ostomy, and Continence Nurses Competency Model: Reliability and Validity
}

\author{
Mayumi Chikubu ${ }^{1 *}$ and Miyako Oike ${ }^{2}$
}

\author{
${ }^{1}$ Graduate School of Health Sciences, Graduate School of Medical \\ Sciences, Kyushu University, Japan. \\ ${ }^{2}$ Professor, Department of Nursing, School of Nursing at Fukuoka, \\ International University of Health and Welfare, Japan.
}

*Correspondence:

Mayumi Chikubu, Doctoral Course in Graduate School of Health Sciences, Graduate School of Medical Sciences, Kyushu University, 3-1-1 Maidashi, Higashi-ku, Japan, Tel: +81-92-642-6703; Fax: +81-92-642-6774; E-mail: mayumi.chikubu.702@s.kyushu-u.ac.jp.

Received: 13 December 2017; Accepted: 04 January 2018

Citation: Mayumi Chikubu, Miyako Oike. An Evaluation Index for the Wound, Ostomy, and Continence Nurses Competency Model: Reliability and Validity. Nur Primary Care. 2018; 2(1): 1-8.

\section{ABSTRACT}

Aim: The competency model of wound, ostomy, and continence nurses (WOCN) in Japan was developed to promote professional roles and evaluate the process of becoming an expert; however, it has not been verified. This study aimed to verify the competency evaluation index for the WOCN competency model.

Methods: This study was a cross-sectional survey design using self-reported questionnaires. Data were collected using anonymous self-administered questionnaires, distributed to 1,792 WOCNs affiliated with hospitals nationwide; of these, 737 questionnaires were included in the analysis.

Results: Factor analysis showed that the competency evaluation index consisted of 5 concepts: action required for the achievement of duty goals, human relationships based on understanding others, WOCN role formation, WOCN professional skills, and WOCN self-study, each with 2 factors. Reliability was assessed via Cronbach's $\alpha$ and Spearman-Brown reliability coefficients; content and construct validity were determined via exploratory factor analysis, the known-group technique, and model conformity. Additionally, significant differences in four competency concepts between WOCNs with $\geq 5$ and $<5$ years' experience as certified nurses suggested that a 5 years' experience distinction was an index of enhanced expertise.

Conclusion: The WOCN competency model could be used as an evaluation index to specify the direction of expertise stages.

\section{Keywords}

Certified nurse, Competency model, Evaluation index, Expert nursing, WOCN.

\section{Introduction}

Nursing contributes to healthcare as a profession, and its functions have become more diverse. The specialty includes nurse practitioners and clinical nurse specialists, and involves wound, ostomy, and continence care, infection control, and critical care [1]. Therefore, how nurses in these specialized fields evaluate their abilities and identify processes for developing expertise are important issues. Wound, ostomy, and continence nurses (WOCNs) work as specialists and provides optimal patient care and instruction for people with wounds, stomata, and incontinence disorders [2]. WOCNs promote patient outcomes while increasing patient satisfaction via advanced practice [3]. In addition, WOCNs' practice areas have expanded to include home-based healthcare that entails prevention and care of pressure ulcers [4] and care of the elderly [5]. They also serve as consultants for individuals with medical conditions [6].

WOCN in Japan was established via the certified nurse $(\mathrm{CN})$ system in 1995 [7]. The role of CNs including WOCNs involves practice, instruction, and consultation. CNs use their expert nursing skills and knowledge to enhance the provision and quality of nursing care in nursing settings and the community, and they provide high-level nursing care in specific nursing fields [7]. Since the launch of the $\mathrm{CN}$ system, evaluation of nursing activities 
involving wound, ostomy, and continence (WOC) care, both within and outside facilities, has increased, and nursing care has been assessed as good in social and economic evaluations [8,9]. In addition, the number of WOCNs has increased rapidly [7]. As a result, WOCNs established the $\mathrm{CN}$ position, and were expected to achieve results within their organizations. However, difficulties in reserving time to perform $\mathrm{CN}$ activities, lack of information about the contents of activities on the part of the surrounding people [10], and role-associated stress [11] have been identified as barriers to the success of WOCNs. Furthermore, WOCNs were asked to improve their professional practical skills by combining nursing practice and self-study [12], and to cooperate with other professionals [13]. Certain problems, such as those involving educational requirements and the legal definition of specialized work, were also reported in other countries [14]. Corbett [15] posited that WOCNs would achieve the best results for patients if they were $\mathrm{CNs}$ and strengthened their collaboration with wound teams. Therefore, WOCNs faced complex challenges, such as those involving organizational activities, and could not demonstrate their roles and responsibilities adequately. In other words, the main challenge faced by WOCNs is a lack of clarity as to whether they can demonstrate expert abilities, knowledge, and skills, and whether they can improve their professional practice. These issues require clarification, and an evaluation index via which to measure the process of change required to become an expert is needed. In particular, as improvements in WOCNs' professional practice skills are required, the measurement of competency is considered helpful for WOCNs, as it is a behavioral characteristic reflecting effective, high-quality nursing activity. Therefore, this study involved the development of a competency model for WOCNs. However, the usefulness of the model has not been verified. The WOCN competency model required verification of the evaluation index for use in WOCNs' self-evaluation and career and role development.

Models for improving nurses' professional abilities include the clinical skill acquisition model of nursing practice [16] and the clinical practice development model [17]. These models represent developmental stages that differ according to nurses' experience, skill acquisition, clinical practice, clinical knowledge, decision making, and collaboration. Their competency is not substantiated or represented as a behavioral characteristic in these models. Measurement of competency, which could involve self-evaluation of nursing practice, is required to demonstrate professional ability. Studies examining behavioral characteristics in nurses have explored competency in advanced-practice registered nurses [18] and diabetes nurses [19]. In addition, competency has been studied in the contexts of educational orientation and pathways [20-22].

Studies examining competency models have considered the leadership competency model [23], and the World Health Organization global competency model [24]. Competency is a broad concept that includes knowledge, skills, and fundamental human characteristics. McClelland [25] clarified common behavior patterns recognized in high achievers, which formed the basis of the competency model. In other words, competency is a behavioral characteristic exhibited by high achievers. The competency model involves a combination of competencies used by high achievers and a description of the specific behaviors displayed when using those competencies. Spencer and Spencer [26] composed a competency dictionary that distinguishes between competencies using stages. WOCNs combine core competencies in advanced nursing practice [14].

TheWOCNSocietyproposed thatWOCNs'competencyinvolves the ability to adapt to patients' circumstances under certain conditions, rather than a demonstration of skills [27], and later presented the magnet model based on the American Nurses Credentialing Center [28]. This is not associated with WOCNs' individual competencies or years of experience. Although variations are recognized in the process of progressing from novice to expert in Advanced Practice Registered Nurse role development, which includes WOCNs, the process of acquiring abilities and qualities corresponding to these stages remains unclear [18]. Therefore, a competency model with a focus on WOCNs has not been developed.

Nishizawa, Sanada, and Kayama [29] reported that Japanese WOCNs' occupational competency could be demonstrated from the perspective of pressure ulcer management. In addition, some studies have examined the components of WOCNs' practical abilities [30] and found that a code of conduct was necessary to ensure that they displayed professional attitudes [31]. Although these studies improved understanding of WOCNs' competency, they did not develop as a code of conduct or evaluation items. Moreover, they did not determine which WOCN behaviors led to practice results or extended the outcomes and roles of nursing practice. No studies have been conducted to examine the behavioral characteristics or skill acquisition processes in WOCNs who have become experts via the accumulation of diverse experience. No research has been conducted to develop a competency model that could guide WOCNs to the stage of expert and represent the process of career development; therefore, the development of a model was necessary.

\section{Material and Methods \\ Aim}

This study aimed to determine the reliability and validity of the competency evaluation index in the WOCN competency model. We hypothesized that expert WOCNs with $\geq 5$ years' experience as CNs would exhibit higher scores than non-expert WOCNs with $<5$ years' experience as CNs.

\section{Competency Model of WOCNs in Japan}

The Competency Model of WOCNs was developed to assess WOCNs' present situation and challenges in Japan [32]. The model was derived from competency information extracted from the content of interviews with 27 expert WOCNs. In the model, the definition of an expert was based on the idea that it requires at least 10 years to become an expert [33], and WOCNs with $>3$ years' nursing experience in the WOC field prior to earning their $\mathrm{CN}$ qualification and 5 years' experience subsequent to earning their qualification were considered experts. Five concepts were 
extracted for the model: "action required for the achievement of duty goals," "human relationships based on understanding others," "WOCN role formation," "WOCN professional skills," and "WOCN self-study." The Competency Model of WOCNs showed that WOCNs could acquire advanced expertise by accumulating experiences and grasping their level of proficiency; it also linked the five competency concepts, which focused on $\mathrm{CN}$ roles in practice, instruction, and consultation.

Study design and sample

This study was a cross-sectional survey design using self-reported questionnaires. This study requested the participation of 1,792 WOCNs nationwide, whose names and hospital affiliations were included in the list of registered CNs on the Japan Nursing Association website. A total of 745 questionnaires were collected (41.6\% collection rate), 737 of which were selected for analysis ( $98.9 \%$ valid response rate).

\section{Instrument}

\section{Drafting evaluation index items}

Questionnaire items were created based on the five competency concepts extracted during the WOCN competency model development. To determine whether questionnaire item content represented the correct balance of appropriate content or items should be added or deleted, the content was confirmed by asking nine WOCNs with $\geq 5$ years' experience. One university professor supervisor also confirmed the content. Their opinions, deleted question items, and modified expressions were summarized, and draft evaluation index items were created.

The draft of the competency evaluation index consisted of 23 items for "action required for the achievement of duty goals," seven items for "human relationships based on understanding others," seven items for "WOCN role formation," 56 items for "WOCN professional skills," and nine items for "WOCN self-study" with a total of 102 evaluation items and five competency concepts. The WOCN competency evaluation index items were measured by a five-point scale ranging from 1 (never able) to 5 (always able), and higher scores indicated greater expertise.

\section{Data collection}

Data were collected between June and August, 2016. The survey content consisted of attributes (sex, age, years of experience as a nurse, years of experience as a certified nurse, and position) and 102 items of the WOCN competency evaluation index. An anonymous, self-administered questionnaire, explanatory documents regarding the research, and a reply envelope were sent to each survey participant via mail. Participants completed the questionnaire and returned it via mail. Return of the questionnaire implied consent to participate in the study.

\section{Ethical considerations}

The study was approved by the ethics review committee at the university with which the first author was affiliated. The researcher presented the study's aim, procedures, and content to participants prior to participation, and their personal information was protected.
Data analysis

Data were analyzed using IBM SPSS Statistics ver.24.0 for Windows, Amos ver.24, and the analysis was supervised by a statistics expert. The following statistical analyses were performed, with the level of significance set at $\mathrm{p}<.05$.

\section{Item Analysis}

After determining the descriptive statistics for each variable, ceiling and floor effects were calculated. Furthermore, item-total correlation analysis, good-poor analysis, and inter-item correlation analyses were also calculated.

\section{Reliability and Validity}

Reliability was assessed by Cronbach's $\alpha$ and Spearman-Brown reliability coefficients. Exploratory factor analysis (principal factor analysis and promax rotation) was performed for each of the five competencies in the WOCN competency model, to assess consistency between questionnaire items and clarify structure. Then the Kaiser-Meyer-Olkin measure (KMO) of sampling adequacy was calculated for the complete model and each variable therein. In addition, principal factor analysis and promax rotation were conducted, and factor numbers were determined from a screen plot of fixed values and factors. The known-group technique, which involves comparison of the scores of multiple groups that are expected to have different characteristics, was also performed. The hypothesis was that expert WOCNs with $\geq 5$ years' experience as CNs would exhibit higher scores relative to those of non-expert WOCNs with $<5$ years' experience. WOCNs were assigned to one of two groups: those with $\geq 5$ years' experience and those with $<5$ years' experience as CNs. Then the hypothesis was tested based on significant differences by performing t-tests to analyze the competency evaluation index items and factors for the competency concepts.

\section{Model goodness of fit}

Confirmatory factor analysis was conducted using the latent variable factors that were ultimately adopted as factors in exploratory factor analysis. The goodness of fit of the competency evaluation index model was determined by calculated values of the goodness-of-fit index (GFI), adjusted goodness-of-fit index (AGFI), root mean square residual (RMR), comparative fit index (CFI), and root mean square error of approximation (RMSEA).

\section{Results}

Participants' demographic characteristics

The majority of the participants were female (94.1\%). Participants' mean age was $42.8($ Standard deviation $(\mathrm{SD})=6.54)$ years. The mean number of years of experience as a nurse was $20.6(\mathrm{SD}=6.57)$, and the largest proportion of years of experience as a nurse was 10-19 years' experience $(50.1 \%)$. The mean number of years of experience as a $\mathrm{CN}$ was $6.7(\mathrm{SD}=3.68)$, and the proportion of participants with 5-9 years' experience (51.7\%) was the largest. In addition, Chief Nurses or Assistant Head Nurses were $49.1 \%$ of participants.

Table 1 shows the participants' demographic characteristics. 
Table 1: Subjects' demographic characteristics $(\mathrm{N}=737)$.

\begin{tabular}{|c|c|c|c|c|c|}
\hline \multicolumn{2}{|c|}{ Characteristic } & $n$ & $\%$ & $M$ & $S D$ \\
\hline \multirow{3}{*}{ Sex } & Male & 43 & 5.8 & & \\
\hline & Female & 693 & 94.1 & & \\
\hline & Unknown & 1 & 0.1 & & \\
\hline \multirow{5}{*}{ Age } & $25-30$ years & 4 & 0.5 & \multirow{5}{*}{42.8} & \multirow{5}{*}{6.54} \\
\hline & $31-40$ years & 286 & 38.8 & & \\
\hline & $41-50$ years & 364 & 49.4 & & \\
\hline & $\geq 51$ years & 81 & 11.0 & & \\
\hline & Unknown & 2 & 0.3 & & \\
\hline \multirow{5}{*}{$\begin{array}{l}\text { Years of } \\
\text { experience as } \\
\text { a nurse }\end{array}$} & $5-9$ years & 23 & 3.1 & \multirow{5}{*}{20.6} & \multirow{5}{*}{6.57} \\
\hline & $10-19$ years & 369 & 50.1 & & \\
\hline & 20-29 years & 292 & 39.6 & & \\
\hline & $\geq 30$ years & 50 & 6.8 & & \\
\hline & Unknown & 3 & 0.4 & & \\
\hline \multirow{4}{*}{$\begin{array}{c}\text { Years of } \\
\text { experience } \\
\text { as a certified } \\
\text { nurse }\end{array}$} & $1-4$ years & 284 & 38.5 & \multirow{4}{*}{6.7} & \multirow{4}{*}{3.68} \\
\hline & $5-9$ years & 381 & 51.7 & & \\
\hline & $10-14$ years & 38 & 5.2 & & \\
\hline & $\geq 15$ years & 34 & 4.6 & & \\
\hline \multirow{5}{*}{ Position } & Staff Nurse & 256 & 34.7 & & \\
\hline & $\begin{array}{l}\text { Chief Nurse / Assistant Head } \\
\text { Nurse }\end{array}$ & 362 & 49.1 & & \\
\hline & Head Nurse & 105 & 14.3 & & \\
\hline & Deputy Nursing Director & 11 & 1.5 & & \\
\hline & Nursing Director & 3 & 0.4 & & \\
\hline
\end{tabular}

Note. $\mathrm{M}=$ mean; $\mathrm{SD}=$ standard deviation.

\section{WOCN competency evaluation index}

Ceiling and floor effects, item-total correlation analysis, goodpoor analysis

Assessment of the ceiling and floor effects for the 102 competency evaluation index items indicated that only one item showed a ceiling effect. However, we examined the content of the item and the score distribution bias, and it was essential for the measurement of competency evaluation. Therefore, we included all 102 items in the analysis. The item-total correlation analysis included coefficients for both item and overall scores. Correlations between competency evaluation index items all exceeded .40 and ranged from .42 to .76, and none of the items were deleted. The results of the good-poor analysis showed a significant difference $(p<.05)$ between groups, indicating that the question items were appropriate.

\section{Inter-item correlation analysis}

Results of the inter-item correlation analysis of the competency evaluation index items showed that the coefficients for 16 sets of correlated items exceeded .70. After examining item content and similarity, we deleted three items from the competency evaluation index and retained the remaining 99 items.

\section{Reliability}

Cronbach's $\alpha$ for the competency evaluation index items exceeded .70 and ranged from .73 to .96 (Table 2). The Spearman-Brown split-half reliability coefficient was .93 . Therefore, the competency evaluation index items demonstrated good reliability.

Table 2: Factor analysis of competency evaluation items.

\begin{tabular}{|c|c|c|}
\hline Competency Concepts & Items & Factor \\
\hline Factor 1, Factor 2 & Hens & Loading \\
\hline Action Required for th & Achievement of Duty Goals & \\
\hline 1: Adjustment & $\begin{array}{l}16 \text { Clarifies negotiations concisely according to } \\
\text { organizational position }\end{array}$ & .87 \\
\hline $\begin{array}{l}\text { Activities Aimed at } \\
\text { Achievement }\end{array}$ & $\begin{array}{l}17 \text { Negotiates in win-win relationships as a WOCN } \\
\text { expert }\end{array}$ & .87 \\
\hline Cronbach's $\alpha=.94$ & $\begin{array}{l}18 \text { Acts to participate in hospital management from } \\
\text { a pioneering perspective }\end{array}$ & .82 \\
\hline 2. Analytical & 03 Analyzes data regarding WOCN care objectively & .92 \\
\hline $\begin{array}{l}\text { Application of } \\
\text { Information }\end{array}$ & $\begin{array}{l}04 \text { Reports, contacts, and consults with managers } \\
\text { and doctors using data }\end{array}$ & .82 \\
\hline Cronbach's $\alpha=.85$ & $\begin{array}{l}02 \text { Understands skin disorder patients in the facility } \\
\text { completely }\end{array}$ & .71 \\
\hline Human Relationships I & ased on Understanding Others & \\
\hline 1. Conscious & $\begin{array}{l}28 \text { Takes time to regain calmness when others' } \\
\text { emotions run high }\end{array}$ & .86 \\
\hline Communication Skills & $\begin{array}{l}29 \text { When there is a disagreement, temporarily and } \\
\text { humbly accepts others' positions }\end{array}$ & .77 \\
\hline Cronbach's $\alpha=.77$ & $\begin{array}{l}30 \text { Draws necessary assistance from others by } \\
\text { through careful listening }\end{array}$ & .69 \\
\hline & 25 Replies to others promptly & .91 \\
\hline Communication Skills & 24 Deals with others in a respectful manner & .55 \\
\hline Cronbach's $\alpha=.73$ & $\begin{array}{l}26 \text { Talks to others in times of need, to identify } \\
\text { communication cues }\end{array}$ & .42 \\
\hline WOCN Role Formatio & & \\
\hline 1: Awareness and & 32 Voices his or her claim. & .91 \\
\hline $\begin{array}{l}\text { Demonstration } \\
\text { of One's Own }\end{array}$ & $\begin{array}{l}34 \text { Explains to staff nurses one's own } \\
\text { responsibilities as a WOCN }\end{array}$ & .59 \\
\hline Cronbach's $\alpha=.78$ & $\begin{array}{l}33 \text { Acts with recognition of one's own } \\
\text { responsibilities as a WOCN }\end{array}$ & .50 \\
\hline & 35 Recognizes and controls one's own emotions & .78 \\
\hline on Role Understanding & $\begin{array}{l}31 \text { Self-reflective and knows one's own behavioral } \\
\text { characteristics as a WOCN }\end{array}$ & .43 \\
\hline Cronbach's $\alpha=. / 4$ & 36 Acts with belief and pride in being a WOCN & .41 \\
\hline WOCN Professional Sl & & \\
\hline 1: Professional Practice & $\begin{array}{l}44 \text { Uses expert knowledge of WOC care and } \\
\text { evaluates care based on local observation }\end{array}$ & .93 \\
\hline & 38 Uses expert knowledge of WOC care and observes & .90 \\
\hline Cronbach's $\alpha=.96$ & $\begin{array}{l}41 \text { Integrates information, such as patients' } \\
\text { individuality, and makes assessments }\end{array}$ & .89 \\
\hline & $\begin{array}{l}85 \text { Cultivates staff nurses' thought processes by } \\
\text { reviewing the nursing practice process }\end{array}$ & .89 \\
\hline $\begin{array}{l}\text { 2: Educational } \\
\text { Instruction Skills }\end{array}$ & $\begin{array}{l}80 \text { Creates experiential learning that allows self- } \\
\text { reflection, to ensure that staff nurses remain } \\
\text { connected to patients' feelings }\end{array}$ & .85 \\
\hline Cronbach's $\alpha=.96$ & $\begin{array}{l}89 \text { Builds relationships to ensure that staff nurses } \\
\text { are aware of the nursing role and actively change } \\
\text { their behavior }\end{array}$ & .81 \\
\hline WOCN Self-Study & & \\
\hline 1. Pursuit of Excel & $\begin{array}{l}100 \text { Speaks in a way that others can understand and } \\
\text { wants to do it together }\end{array}$ & .87 \\
\hline & 95 Responds to others with an open mind & .79 \\
\hline Cronbach's $\alpha=.84$ & $\begin{array}{l}94 \text { Devises ways to enhance sensitivity, to } \\
\text { understand patients' holistic health }\end{array}$ & .66 \\
\hline
\end{tabular}




\begin{tabular}{|l|l|c|}
\hline \multirow{2}{*}{$\begin{array}{l}\text { 2: Knowledge } \\
\text { Acquisition for Self- }\end{array}$} & $\begin{array}{l}\text { 97 Acquires new knowledge by participating in } \\
\text { training, and reading articles and journals }\end{array}$ & .88 \\
\cline { 2 - 3 } Culfilment & $\begin{array}{l}\text { 98 Acquires knowledge of social situations } \\
\text { regarding the WOC field }\end{array}$ & .88 \\
\cline { 2 - 3 } Cronbach's $\alpha=.85$ & $\begin{array}{l}\text { 96 Acquires knowledge necessary for information } \\
\text { gathering analysis }\end{array}$ & .44 \\
\hline
\end{tabular}

Note. $\mathrm{N}=737$; $\mathrm{WOC}=$ wound, ostomy, and continence; $\mathrm{WOCN}=$ wound, ostomy, and continence nurse.

Factor extraction, main factor method, and rotation method: promax with Kaiser Normalization.

\section{Validity}

The results of the top three items of the exploratory factor analysis (principal factor analysis and promax rotation) for each of the five competency concepts in the WOCN competency model and factor structure are shown in Table 2. The KMO values were as follows: .95 for "action required for the achievement of duty goals," .83 for "human relationships based on understanding others," .88 for "WOCN role formation," .98 for "WOCN professional skills," and .89 for "WOCN self-study." The KMO sample validity values for all competency concepts exceeded .80 , which confirmed that there was value in performing the factor analysis. Items with factor loadings of $<.40$ were deleted, and further factor analysis was carried out. Prior to rotation, the cumulative contribution ratios for concepts with two factors were as follows: $49.96 \%$ for "action required for the achievement of duty goals," $52.71 \%$ for "human relationships based on understanding others," $49.83 \%$ for "WOCN role formation," $51.26 \%$ for "WOCN professional skills," and $58.67 \%$ for "WOCN self-study."

Ultimately, the competency evaluation index consisted of two factors and 23 items for "action required for the achievement of duty goals," two factors and seven items for "human relationships based on understanding others," two factors and seven items for "WOCN role formation," two factors and 51 items for "WOCN professional skills" (with two items deleted), and two factors and eight items for "WOCN self-study" (with one item deleted). There were 96 items in the competency evaluation index.

\section{Factor naming}

Based on the results of the exploratory factor analysis, we named the factors in consideration of the items that showed the highest factor loadings. "Actions required for the achievement of duty goals" consisted of 16 items for Factor 1 and seven items for Factor 2 , which we named "adjustment activities aimed at achievement" and "analytical application of information," respectively. "Human relationships based on understanding others" consisted of four items for Factor 1 and three items for Factor 2, which we named "conscious communication skills" and "everyday communication skills," respectively. "WOCN role formation" consisted of three items for Factor 1 and four items for Factor 2, which we named "awareness and demonstration of one's own responsibilities" and "contributions based on role understanding," respectively. "WOCN professional skills" consisted of 27 items for Factor 1 and 24 items for Factor 2, which we named "professional practical skills" and "educational instruction skills," respectively. "WOCN self-study" consisted of five items for Factor 1 and three items for
Factor 2, which we named "pursuit of excellence" and "knowledge acquisition for self-fulfillment," respectively.

\section{Known-group technique}

Total scores for the competency factors according to number of years' experience as a $\mathrm{CN}$ are shown in Table 3, and total scores for the evaluation items for "human relationships based on understanding others" according to number of years' experience as a $\mathrm{CN}$ are shown in Table 4. The $\mathrm{t}$ test results showed significant differences between WOCNs with $\geq 5$ and $<5$ years of experience as $\mathrm{CNs}$ in the competency concepts "actions required for the achievement of duty goals," "WOCN role formation," "WOCN professional skills," and "WOCN self-study." "Human relationships based on understanding of others" in the competency concepts did not differ significantly between the two groups. However, "replies to others promptly" in the competency evaluation index items differed significantly between the two groups.

Table 3: Total scores for competency factors according to experience.

\begin{tabular}{|c|c|c|c|c|c|c|c|}
\hline \multirow{2}{*}{\multicolumn{2}{|c|}{\begin{tabular}{|c|} 
Competency Concepts \\
Competency Factors
\end{tabular}}} & \multicolumn{2}{|c|}{$\begin{array}{l}<5 \text { Years } \\
(n=284)\end{array}$} & \multicolumn{2}{|c|}{$\begin{array}{l}\geq 5 \text { Years } \\
(n=453)\end{array}$} & \multicolumn{2}{|c|}{$\begin{array}{l}\text { Difference in } \\
\text { Mean Values }\end{array}$} \\
\hline & & \multirow{2}{*}{$\begin{array}{c}\boldsymbol{M} \\
3.38\end{array}$} & \multirow{2}{*}{$\begin{array}{l}S D \\
0.65\end{array}$} & \multirow{2}{*}{$\begin{array}{c}\boldsymbol{M} \\
3.75\end{array}$} & \multirow{2}{*}{$\begin{array}{l}S D \\
0.60\end{array}$} & \multirow{2}{*}{$\begin{array}{c}t \\
-7.867\end{array}$} & \multirow{2}{*}{$\begin{array}{c}\boldsymbol{p} \\
<.001\end{array}$} \\
\hline $\begin{array}{l}\text { Action } \\
\text { Required }\end{array}$ & $\begin{array}{c}\text { Adjustment } \\
\text { Activities Aimed } \\
\text { at Achievement }\end{array}$ & & & & & & \\
\hline $\begin{array}{l}\text { for the } \\
\text { Achievement } \\
\text { of Duty Goals }\end{array}$ & $\begin{array}{l}\text { Analytical } \\
\text { Application of } \\
\text { Information }\end{array}$ & 3.56 & 0.69 & 3.90 & 0.65 & -6.816 & $<.001$ \\
\hline \multirow{2}{*}{$\begin{array}{c}\text { Human } \\
\text { Relationships } \\
\text { Based on } \\
\text { Understanding } \\
\text { Others }\end{array}$} & $\begin{array}{l}\text { Conscious } \\
\text { Communication } \\
\text { Skills }\end{array}$ & 3.60 & 0.66 & 3.65 & 0.64 & -0.904 & .366 \\
\hline & $\begin{array}{l}\text { Everyday } \\
\text { Communication } \\
\text { Skills }\end{array}$ & 4.10 & 0.56 & 4.18 & 0.55 & -1.947 & .520 \\
\hline \multirow{2}{*}{$\begin{array}{l}\text { WOCN Role } \\
\text { Formation }\end{array}$} & $\begin{array}{l}\text { Awareness and } \\
\text { Demonstration } \\
\text { of One's Own } \\
\text { Responsibilities }\end{array}$ & 3.68 & 0.67 & 3.84 & 0.61 & -3.317 & .001 \\
\hline & $\begin{array}{l}\text { Contributions } \\
\text { Based on Role } \\
\text { Understanding }\end{array}$ & 3.80 & 0.62 & 3.99 & 0.57 & -4.184 & $<.001$ \\
\hline \multirow{2}{*}{$\begin{array}{l}\text { WOCN } \\
\text { Professional } \\
\text { Skills }\end{array}$} & $\begin{array}{c}\text { Professional } \\
\text { Practical Skills }\end{array}$ & 3.72 & 0.60 & 3.97 & 0.56 & -5.916 & $<.001$ \\
\hline & $\begin{array}{c}\text { Educational } \\
\text { Instruction Skills }\end{array}$ & 3.20 & 0.70 & 3.49 & 0.66 & -5.644 & $<.001$ \\
\hline \multirow{2}{*}{$\begin{array}{l}\text { WOCN Self- } \\
\text { Study }\end{array}$} & $\begin{array}{l}\text { Pursuit of } \\
\text { Excellence }\end{array}$ & 3.39 & 0.68 & 3.65 & 0.70 & -5.052 & $<.001$ \\
\hline & $\begin{array}{l}\text { Knowledge } \\
\text { Acquisition for } \\
\text { Self-Fulfilment }\end{array}$ & 3.82 & 0.69 & 3.94 & 0.67 & -2.217 & 0.027 \\
\hline
\end{tabular}

Note: $\mathrm{M}=$ mean; $\mathrm{SD}=$ standard deviation; $\mathrm{WOCN}=$ wound, ostomy, and continence nurse.

\section{Model goodness of fit}

Results of the confirmatory factor analysis of the factors produced by the exploratory factor analysis and evaluation index items were as follows: $\mathrm{GFI}=.75-.97, \mathrm{AGFI}=.73-.94, \mathrm{RMR}=.02-.05, \mathrm{CFI}=$ $.84-.97, \mathrm{RMSEA}=.07-.13$. Table 5 shows covariance between the factors for each of the five competency concepts in the assumed and calculated models. 
Table 4: Total scores for "human relationships based on understanding others" evaluation items according to experience.

\begin{tabular}{|c|c|c|c|c|c|c|}
\hline \multirow{2}{*}{$\begin{array}{c}\text { Competency Factors } \\
\text { Evaluation Items }\end{array}$} & \multicolumn{2}{|c|}{$\begin{array}{l}<5 \text { Years } \\
(\mathrm{n}=284)\end{array}$} & \multicolumn{2}{|c|}{$\begin{array}{l}\geq 5 \text { Years } \\
(\mathrm{n}=453)\end{array}$} & \multicolumn{2}{|c|}{$\begin{array}{l}\text { Difference in } \\
\text { Mean Values }\end{array}$} \\
\hline & $M$ & $S D$ & $M$ & $S D$ & $t$ & $p$ \\
\hline \multicolumn{7}{|l|}{ Factor 1} \\
\hline \multicolumn{7}{|l|}{ Conscious Communication Skills } \\
\hline $\begin{array}{l}28 \text { Takes time to regain calmness } \\
\text { when others' emotions run high }\end{array}$ & 3.52 & 0.83 & 3.61 & 0.78 & -1.553 & .121 \\
\hline $\begin{array}{l}29 \text { When there is a disagreement, } \\
\text { temporarily and humbly accepts } \\
\text { others' positions }\end{array}$ & 3.83 & 0.77 & 3.77 & 0.75 & 1.129 & .259 \\
\hline $\begin{array}{l}30 \text { Draws necessary assistance } \\
\text { from others by through careful } \\
\text { listening }\end{array}$ & 3.86 & 0.72 & 3.90 & 0.73 & -0.611 & .542 \\
\hline $\begin{array}{l}27 \text { Attends informal meetings and } \\
\text { uses them for human relationships } \\
\text { at work }\end{array}$ & 3.19 & 1.07 & 3.31 & 1.06 & -1.434 & .152 \\
\hline \multicolumn{7}{|l|}{ Factor 2} \\
\hline \multicolumn{7}{|l|}{ Everyday Communication Skills } \\
\hline 25 Replies to others promptly & 4.08 & 0.64 & 4.20 & 0.64 & -2.476 & .014 \\
\hline $\begin{array}{l}24 \text { Deals with others in a respect- } \\
\text { ful manner }\end{array}$ & 4.22 & 0.61 & 4.31 & 0.64 & -1.938 & .053 \\
\hline $\begin{array}{l}26 \text { Talks to others in times of need, } \\
\text { to identify communication cues }\end{array}$ & 4.00 & 0.81 & 4.03 & 0.76 & -0.563 & .574 \\
\hline
\end{tabular}

Note: $\mathrm{M}=$ mean; $\mathrm{SD}=$ standard deviation.

Table 5: Model goodness of fit.

\begin{tabular}{|c|c|c|c|c|c|}
\hline \multirow{2}{*}{ Competency Concept } & \multicolumn{5}{|c|}{ Model Goodness of Fit } \\
\cline { 2 - 6 } & GFI & AGFI & RMR & CFI & RMSEA \\
\hline $\begin{array}{c}\text { Action required for the } \\
\text { achievement of duty goals }\end{array}$ & .80 & .77 & .05 & .84 & .10 \\
\hline $\begin{array}{c}\text { Human relationships based on } \\
\text { understanding others }\end{array}$ & .93 & .86 & .05 & .92 & .13 \\
\hline WOCN role formation & .97 & .94 & .02 & .97 & .08 \\
\hline WOCN professional skills & .75 & .73 & .04 & .84 & .07 \\
\hline WOCN self-study & .92 & .85 & .04 & .93 & .13 \\
\hline
\end{tabular}

Note. AGFI $=$ adjusted goodness-of-fit index; CFI $=$ comparative fit index; GFI = goodness-of-fit index; RMSEA = root mean square error of approximation; RMR = root mean square residual; $\mathrm{WOCN}=$ wound, ostomy, and continence nurse.

\section{Discussion}

Reliability and validity of the competency evaluation index Cronbach's $\alpha$ for the factors with respect to reliability exceeded .70 and ranged from .73 to .96 . In addition, the Spearman-Brown reliability coefficient (.93) demonstrated good internal consistency.

Validity was verified by content validity and construct validity. The items in the competency evaluation index with respect to content validity were created based on the concepts extracted from qualitative research examining WOCN competency model development and content. This content was approved of by WOCNs with $\geq 5$ years' experience as a CN. The number of competency evaluation index items decreased from 102 to 96 based on the analysis, and a few items were excluded. Therefore, the results demonstrated content validity.

Construct validity was verified by exploratory factor analysis, the known-group technique, and model goodness of fit. The exploratory factor analysis was able to analyze the five competency concepts and extract two factors for each concept. The KMO sample validity results exceeded .80; therefore, there was value in performing factor analysis. The cumulative contribution ratio for two factors prior to rotation for each concept was comparatively high at $49-58 \%$. Therefore, some degree of agreement was observed between the construct validity and the concepts, and validity was demonstrated. The known-group technique showed that the competency concepts, except for "human relationships based on understanding others," differed significantly between WOCNs with $\geq 5$ and $<5$ years' experience as CNs. In other words, the hypothesis that WOCNs with greater experience would exhibit greater competency, relative to that of those with less experience, was supported. The competency evaluation index was considered to possess discriminatory power and good validity. In addition, model goodness of fit fulfilled the GFI $>$ AGFI criterion, indicating that the model closely matched the RMR data and the model conformed to the CFI data. The factors "human relationships based on understanding others" and "WOCN self-study" were slightly higher than the 0.1 standard in RMSEA. The model goodness of fit showed adequate goodness of fit and validity. Therefore, the results of exploratory factor analysis, the known-group technique, and model goodness of fit demonstrated construct validity.

Differences in competency according to number of years' experience as a $\mathrm{CN}$

The analysis results showed that four competency concepts differed significantly between WOCNs with $\geq 5$ and $<5$ years' experience as CNs. The results are consistent with the findings of previous research in which nurses with greater experience displayed greater expertise relative to those with less experience $[34,35]$. WOCNs with $\geq 5$ years' experience as $\mathrm{CNs}$ are a central part of WOC nursing, and it is presumed that they demonstrate high levels of expertise. In particular, they likely have accumulated experiential knowledge. Matsuo [36] posited that experience leads to confidence acquisition, willingness to strive for and pursue learning opportunities, and learning flexibility. In addition, challenging experiences have been shown to increase ability and growth [37]. The results were consistent with this finding, as they showed that experiential knowledge enhanced professional knowledge and the acquisition of expert skills in WOCNs with $\geq 5$ years' experience as CNs. Therefore, the competency concepts in this model reflected the acquisition of ability and skill via experiential knowledge. Moreover, the 5 years' experience as a CN distinction was an indicator for improvement of WOCNs' expertise. WOCNs can become aware of the change process and the extent of their expertise by the competency evaluation indicators, and identify the direction needed to become experts.

In contrast, "human relationships based on understanding others" did not differ significantly according to experience. One reason for this finding could be that WOCNs' duties differed from those of staff 
nurses, who provide 24-hour bedside care and perform their work under time constraints. The quantity and quality of staff nurses' communication differed from that of WOCNs, and relationships might not have been prioritized as a means of emphasizing professional activities in WOCNs. WOCNs had an average of 20.6 years' experience as nurses and a substantial amount of clinical experience. They also possessed some communication skills, which are at the heart of human relationships; however, they could have been unaware of their communication expertise. As WOCNs' present the wound healing process and preventive skin care advice to others as visual information, their communication tends to be limited. "Human relationships based on understanding others" could have involved a tendency not to focus on communication. The role of the $\mathrm{CN}$ includes instructing patients and families, and "human relationships based on understanding others" could be considered important as a competency concept.

When we considered the evaluation index items for "human relationships based on understanding others," only one item, "replies to others promptly" differed significantly between the two groups. From the perspective of CNs practicing highly specialized nursing, WOCNs are required to reply promptly and solve problems based on instant judgment. Experience is indispensable in making quick judgments and decisions, and we presumed that WOCNs with $\geq 5$ years' experience as CNs made instant judgments of situations, based on experiential knowledge, and made decisions and acted in consideration of priorities. Experts understand situations intuitively and determine the aim of problem solving accurately [16], and they could be considered able to monitor problem-solving procedures and strategies to deal with challenges with an appropriate outlook [38]. This suggests that WOCNs with $\geq 5$ years' experience as CNs possess a combination of superb judgment skills and the ability to make quick decisions and take action. In particular, of the competency evaluation indicators, the "replies to others promptly" item was considered a characteristic evaluation criterion for practical skills.

\section{Strengths and limitations}

Evaluation of the reliability and validity of the competency evaluation index for the WOCN competency model indicated that it is possible to evaluate one's own competency and role acquisition status, based on the relationships between competency concepts. It could enhance WOCNs' expertise and serve as a career development tool. However, the sample was limited to hospitalaffiliated WOCNs; future studies should expand subject samples to include WOCNs affiliated with other facilities.

\section{Conclusion}

The reliability and validity of the competency evaluation index for the WOCN competency model were verified for the first time. The results suggested that WOCNs could use the competency evaluation index to evaluate their professional competence and understand their role acquisition status. They could also become aware of the change process and the extent of their own expertise, and further identify the direction of development required to reach the stage of expert.

\section{References}

1. Graduate Nursing Edu.org [website]. http://www. graduatenursingedu.org/.

2. Wound, Ostomy and Continence Nurses Society [website]. How to become a WOC Nurse. http://www.wocn.org/?page= become_a woc nurse.

3. Medley JA. Cost-effectiveness of a WOC advanced practice nurse in the acute care and outpatient setting. J Wound Ostomy Continence Nurs. 2014; 41: 307-310.

4. Bergquist S. The quality of pressure ulcer prediction and prevention in home health care. Appl Nurs Res. 2005; 18 : 148-154.

5. Bates-Jensen BM. Quality indicators for prevention and management of pressure ulcers in vulnerable elders. Ann Intern Med. 2001; 135: 744-751.

6. Kaufman MW. The WOC nurse Economic quality of life and legal benefits. Dermatol Nurs. 2001; 13: 215-219.

7. Japanese Nursing Association [website]. Qualification authorization system. http:/www.nintei.nurse.or.jp/nursing/ qualification/cn

8. Nagano M, Tanaka H, Miyajima M, et al. Activities and results of wound ostomy continence (WOC) nursing certified expert nurses: Subjective personal survey and evaluation by questionnaire from their superior(s). Journal of Japanese Wound, Ostomy and Continence Nurse Society. 1999; 3: 3439.

9. Nagano M, Ogata Y, Tokunaga K, et al. Effective pressure ulcer measures at hospital as determined from certified wound ostomy and continence nurses perception of influence on quality control and the incidence of pressure ulcers. Journal of Japanese Society Wound Ostomy and Continence Management. 2014; 18: 293-304.

10. Kamisaka T, Matsushita T, Oura Y. The cognition for activity and application of certified nurses (CNs): The comparison between nursing administrators, CNs, and nurses. Journal of Japan Society of Nursing Research. 2010; 33: 73-84.

11. Miyakubi Y, Kameoka T. Current status of role stress among certified nurses in Japan: Comparison among joint appointees, semi-joint appointees, and non-joint appointees. Journal of Nursing Studies. 2013; 12: 8-16.

12. Ishikubo Y, Iwata H, Nozawa A. A study on the abilities of certified expert nurses in specialized practices. Journal of Japan Academy of Nursing Science. 2004; 24: 81-87.

13. Fujiwara E, Saito N, Taru C, et al. Collaboration by wound ostomy and continence nurses in pressure ulcer management. Journal of Japanese Society of Wound Ostomy and Continence Management. 2014; 18: 20-28.

14. Beitz JM. Specialty practice, advanced practice, and WOC nursing: Current professional issues and future opportunities. J Wound Ostomy Continence Nurs. 2000; 27: 55-64.

15. Corbett LQ. Wound care nursing Professional issues and opportunities. Adv Wound Care. 2012; 1: 189-193.

16. Benner P. From novice to expert: Excellence and power in clinical nursing. Menlo Park, CA: Addison-Wesley 1984.

17. Haag-Heitman B, Kramer A. Creating a clinical practice: Development model. Am J Nurs. 1998; 98: 39-43. 
18. Hamric B, Spross A, Hanson M. Advanced practice nursing: An integrative approach. St Louis, MO: Saunders 2009.

19. Davis R, Turner E, Hicks D, et al. Developing an integrated career and competency framework for diabetes nursing. Journal of Clinical Nursing. 2008; 17: 168-174.

20. Cattini P, Knowles V. Core competencies for clinical nurse specialists: A usable framework. Journal of Clinical Nursing. 1999; 8: 505-511.

21. DiMauro K, Mack LB. A competency-based orientation program for the clinical nurse specialist. J Contin Educ Nurs. 1989; 20: 74-78.

22. Young L, Frost LJ, Big J, et al. Nurse educator pathway project: A competency-based intersectoral curriculum. International Journal of Nursing Education Scholarship. 2010;42:1-13.

23. Sherman RO, Bishop M, Eggenrger T, et al. Development of a leadership competency model. J Nurs Admin. 2007; 37: 8594.

24. World Health Organization [website]. WHO Global Competency Model. http://www.who.int/employment/ competencies/WHO_competencies_EN.

25. McClelland DC. Testing for competence rather than for intelligence. Am Psychol. 1973; 28: 1-14.

26. Spencer LM Jr, Spencer SM. Competence at work: Models for superior performance. New York, NY: Wiley 1993.

27. Kupsick PT. Challenging how competency is validated: The wound, ostomy and continence nurse society issues a position statement. Am J Nurs. 2005; 105: 90-91.

28. Wound, Ostomy and Continence Nurses Society. Magnet recognition and the role of the wound, ostomy and continence nurse fact sheet. http://www.wocn.org/news/93505/Magnet-
Recognition-and-the-Role-of-the-Wound-Ostomy-andContinence-Nurse-Fact-Sheet.htm

29. Nishizawa T, Sanada H, Kayama M. Development of a competency model of wound ostomy and continence nurses for pressure ulcer management. Japanese Journal of Pressure Ulcers. 2008; 10: 117-121.

30. Kataoka H. The skill stage and practical ability of certified wound, ostomy and continence nurses. Journal of Japanese Wound Ostomy and Continence Nurse Society. 2009; 12: 1219.

31. Honda Y. A study regarding code-practice for nursing experts. The Bulletin of Saitama Prefectural University. 2006; 8: 133137.

32. Chikubu M, Oike M. Wound, Ostomy and Continence Nurses Competency Model: A Qualitative Study in Japan. Journal of Nursing \& Healthcare. 2017; 2: 1-7.

33. Ericsson AK, Krampe R. TH, Tesch-Romer C. The role of deliberate practice in the acquisition of expert performance. Psychol Rev. 1993; 100: 363-406.

34. Tanaka M, Yonemitsu Y, Kawamoto R. Nursing professional: A national survey of professionalism among Japanese nurses. Int J Nurs Pract. 2014; 20: 579-587.

35. Wynd CA. Current factors contributing to professionalism in nursing. J Prof Nurs. 2003; 19: 251-261.

36. Matsuo M. Learning from experience: The process of professional development. Tokyo: Dobunkan Shuppan; 2006.

37. McCall MW. High flyers: Developing the next generation of leaders. Boston, MA: Harvard Business School Press; 1998.

38. Hatano G. Learning and development: Cognitive psychology 5. Tokyo: University of Tokyo Press; 1996.

(C) 2018 Chikubu M \& Oike M. This article is distributed under the terms of the Creative Commons Attribution 4.0 International License 